\title{
Outcome of first line antiretroviral therapy (art) with respect to treatment Failure at ART CENTRE, B. J. Medical College, Civil Hospital, Ahmedabad
}

Bipin Amin, Urvi Derasari, Umesh Nihalani, Hemang Purohit, Manoj Shevkani', Sanjeev Prajapati, Girish Prajapati, Bankim Mankad, Asha Shah, Burzin Kavina

From $16^{\text {th }}$ International Symposium on HIV and Emerging Infectious Diseases Marseille, France. 24-26 March 2010

\section{Background}

To Study outcome of $1^{\text {st }}$ Line Anti Retroviral Therapy (ART) at with respect to treatment failure at ART Centre, B. J. Medical College, Civil Hospital, Ahmedabad, Gujarat, India.

\section{Methods}

All the ever started $1^{\text {st }}$ Line ART patients were evaluated for treatment failure as per Indian National ART Guidelines at our institute.

\section{Results}

ART Centre, B. J. Medical College, Civil Hospital was started on $25^{\text {th }}$ April, 2005. Till October 2009 ever registered patients are 11827 among this total 5847 patients were initiated ART as per Indian National ART Guidelines, Table 1.

\section{Discussion}

The clinical goals of HIV treatment are optimally accomplished through consistent high-level adherence to Highly Active Anti Retroviral Therapy (HAART) and sustained virological suppression through cost effective regimen (2NRTIs+1NNRTI). At the end of more than 4 years total suspected IF patients are only $73(2.13 \%)$ of which only $49(1.70 \%)$ has actual virological failure; shows the efficacy of the $1^{\text {st }}$ Line ART. Failure to access care and discontinuation of or non-adherence to ART are the most important factors associated with the progression of HIV disease.

\footnotetext{
* Correspondence: coe.art.ahmedabad@gmail.com ART center B J Medical College, Ahmedabad, India
}

Table 1

\begin{tabular}{ll}
\hline Parameter & Outcome \\
\hline Total Patients initiated ART & 5847 \\
Total Patients alive on ART at the end of October 2009 & $2880(49.25 \%)$ \\
Immunological Failure (IF) patients & $73(2.13 \%)$ \\
$(\mathrm{n}=3414$; Excluding Deaths and Transfer Out) & \\
Referred for Plasma Viral Load (PVL) & $68(94.4 \%)$ \\
PVL $<400$ copies/ml (A) & $19(28 \%)$ \\
$400-10,000$ copies/ml (B) & $06(8.8 \%)$ \\
$>10,000$ copies/ml (C) & $43(63.2 \%)$ \\
Total patients failing as per Virological Failure (B+C) & $49(1.70 \%)$ \\
$(n=2880)$ & \\
\hline
\end{tabular}

Published: 11 May 2010

doi:10.1186/1742-4690-7-S1-P49

Cite this article as: Amin et al:: Outcome of first line antiretroviral therapy (art) with respect to treatment Failure at ART CENTRE, B. J. Medical College, Civil Hospital, Ahmedabad. Retrovirology 2010 7(Suppl 1):P49.

Submit your next manuscript to BioMed Central and take full advantage of:

- Convenient online submission

- Thorough peer review

- No space constraints or color figure charges

- Immediate publication on acceptance

- Inclusion in PubMed, CAS, Scopus and Google Scholar

- Research which is freely available for redistribution

Submit your manuscript at www.biomedcentral.com/submit 